This item was submitted to Loughborough's Research Repository by the author.

Items in Figshare are protected by copyright, with all rights reserved, unless otherwise indicated.

\title{
Automobile use within selected island states
}

PLEASE CITE THE PUBLISHED VERSION

PUBLISHER

(C) Elsevier

VERSION

AM (Accepted Manuscript)

LICENCE

CC BY-NC-ND 4.0

REPOSITORY RECORD

Enoch, Marcus P., and James P. Warren. 2019. "Automobile Use Within Selected Island States". figshare. https://hdl.handle.net/2134/4294. 
This item was submitted to Loughborough's Institutional Repository (https://dspace.lboro.ac.uk/) by the author and is made available under the following Creative Commons Licence conditions.

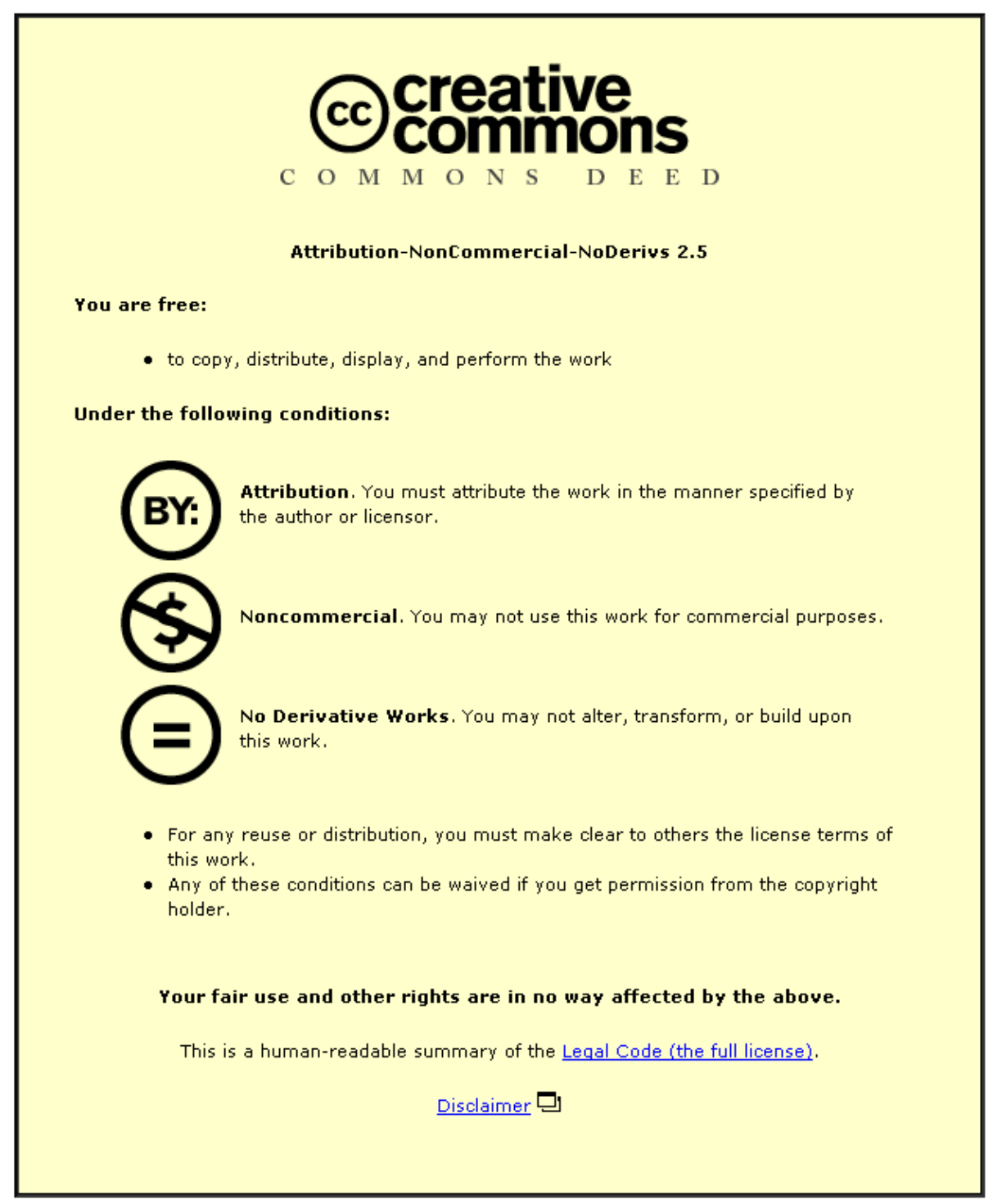

For the full text of this licence, please go to: http://creativecommons.org/licenses/by-nc-nd/2.5/ 


\title{
Automobile use within selected island states
}

\author{
Marcus P Enoch* and James P Warren** \\ * Transport Studies Group, Department of Civil and Building Engineering, Loughborough University, \\ Leicestershire LE11 3TU, UK. Tel: +44 1509 223408. Fax: +44 1509 223981. ** Design \& Innovation \\ Group, The Open University, Cintra House, 12 Hills Rd, Cambridge CB2 1PF, UK. Tel: +44 1223364721 , \\ Fax: +44 1223355207 (corresponding author).
}

\begin{abstract}
Transport use in island states shares many of the same characteristics as other developing countries, but with added complications of geographic isolation and lack of capital for many islanders. This paper examines the influence of the automobile in 45 Small Island Developing States (SIDS), as defined by the United Nations, using multiple regression techniques. Under these cross sectional processes, car based mobility is tested against factors including gross domestic product, population, vehicle ownership, road length, and urbanisation, data for which is obtained from a range of primary and secondary sources for a subset of 38 island states.

The analysis shows a strong relationship between increased mobility and increased GDP, while other factors which appear to be important included population density and vehicles per unit road length. The model results are then compared and contrasted with average apparent global mobility figures from a much larger set of countries, and this shows that mobility is significantly lower (almost half) that of comparably wealthy non SIDS.
\end{abstract}

Keywords: small island developing states, SIDS, automobile, vehicle, mobility, ownership, use, motorisation, GDP, nissology, island studies

\section{Introduction}

Car use - and the economic, social and environmental impact that this activity generates - is rapidly increasing in countries across the world. While much of this expansion is occurring in richer nations, growth in many poorer nations is also taking place and in many cases is becoming increasingly problematic.

\subsection{Key characteristics of island states}

Islands are attractive to researchers because they are detached, self-contained entities with obvious boundaries. From a geographers' perspective, this has long been recognised as a distinct advantage, with islands effectively 'functioning as small-scale spatial laboratories where theories can be tested and processes observed in the setting of a semi-closed system' (King, 1993 and McCall, 1994). However from the viewpoint of the policy maker on an island state, this is a distinct disadvantage as these 'island systems' already face many of the problems faced by more developed countries, but with less time, experience and resources to devise a solution before the situation becomes critical due to the faster growth of population and the economy (Gakenheimer, 1999), coupled with a lack of space.

Islands have a combination of economic, social/cultural, geographic, climatic and environmental characteristics that distinguish them from larger and landlocked developing countries (Lockhart et al, 1993; Kakazu, 1994; Weisser, 2004, Briguglio, 1995). The interaction of these island-specific attributes generates a set of development problems that are often very different from those faced by larger countries'. In particular, intrinsic economic constraints have considerable influence on the economic structure and performance of an island. The most obvious limitation that islands have to endure relates to their geographic parameters of smallness and remoteness, as well as the acute outward-looking economic orientation. The combined influences can cause significant economic vulnerability and an inability to pursue economic development without substantial economic support. Finally, the smallness of island states leads to limited capacities both in terms of production and consumption. They are rarely in a position to develop economies of scale and cannot create substantial internal markets, as well as unable to raise large amounts of capital/finance on the home market. In many of these islands there is strong reliance on both aid and external remittances. These characteristics are summarised in Table 1. 
Table 1: Intrinsic vulnerabilities in island states, adapted from sources: Pelling and Uitto (2001), Lockhart et al (1993), Conway (1998), Armstrong and Read (2006) and Slade (1999).

\begin{tabular}{ll}
\hline Factor & Vulnerability examples \\
\hline Smallness & Limited natural resource base, \\
& high competition between land use, \\
& intensity of land use, \\
& immediacy of interdependence in human-environment systems, \\
& spatial concentration of productive assets. \\
Remoteness and & High external transport costs, \\
Insularity & time delays and high costs in accessing external goods, \\
& delays and reduced quality in information flows, \\
Demographic factors & geopolitically weakened \\
& Limited human resource base, \\
& small population, \\
& rapid population changes, \\
& single urban centre, \\
population concentrated on coastal zone, \\
dis-economies of scale leading to high per capita costs for infrastructure and \\
services \\
Small economies, \\
dependence on external finance, \\
small internal market, \\
dependence on natural resources, \\
high specialisation of production
\end{tabular}

Although worldwide there are nearly 2000 'significant' islands of which only some are inhabited (UN, 1998), obtaining data for the vast majority of these would be problematic and so the focus of this paper has been to look exclusively at the 45 so-called Small Island Developing States (SIDS) as defined by the United Nations (UN, 2003b). It should be noted that this list includes not only 'islands', but also 'low-lying coastal countries that share similar sustainable development challenges, including small population, lack of resources, remoteness, susceptibility to natural disasters, excessive dependence on international trade and vulnerability to global developments. In addition, they suffer from the similar issues such as lack of economies of scale, high transportation and communication costs, and costly public administration and infrastructure. A further point is that some more developed island nations such as Singapore, Cyprus and the Netherlands Antilles are included in the initial dataset. Some of the SIDS indeed are islands which are connected to the mainland (e.g. Singapore and Bahrain) and thus experience the bridge-effect (Baldacchino, 2005). This undoubtedly affects overall mobility. Those nations which are connected to the mainland directly (e.g. Belize, Guinea-Bissau, Guyana, Suriname) will also be influenced by their neighbouring countries in terms of mobility. It should also be noted that in some cases the islands are not that small (e.g. Cuba) and that by some monetary frameworks others are probably not strictly 'developing' but rather developed. Nevertheless the SIDS grouping provides useful construct.

In this work we attempt to find commonalities based on transport trends and practices. Island specific issues are too diverse to adequately summarise here, thus here only land transport issues are addressed. For full details of some of the issues examined for certain states see the Appendix.

\subsection{Factors affecting vehicle use}

Briefly, there have been a number of studies looking at factors affecting car use across a range of countries. For instance, in a longitudinal review of cars and usage from 1958 to 1980 in 19 (developed) countries, Tanner (1983) finds that 'among the clearest and strongest influences are those of income levels on the number of cars, and of petrol prices on the sizes of cars and hence how much petrol they use.'

More directly relevant, as it focuses on less developed countries, Button et al (1993) reviews vehicle ownership and use and finds again there is a strong relationship between car ownership and the rate of economic growth. Fuel price and income were found to be important influences in the short term. The study models vehicle ownership and use in low income countries, but specifically leaves out small island states as 'special circumstances may influence underlying causal relationships'. The paper concludes that at the national level the main independent variable influencing ownership is income, while additional variables include the price of fuel, the level of urbanisation and the degree of industrialisation. Car use depends primarily on the level of vehicle ownership, followed by income, the price of fuel, the degree of urbanisation and the extent of the road network. Also relating to developing countries, Simon (1996) suggests that in addition to per capita income, car ownership levels also depend on factors including country size, infrastructure availability, quality, affordability, availability of public transport services, cultural, social and religious values, state policies, and income distribution within the country being considered. Lastly, Vasconcellos (2001) notes that car use is dependent on income, gender, age, occupation and educational level, and that it is highly influenced by economic and spatial constraints. Thus, Western 
Europeans have higher per capita incomes than US citizens and yet they travel less by car, while the wealthy Asian countries have a $20 \%$ lower income than the US but travel seven times less by car.

Gakenheimer (1999) reports that car ownership is correlated with the top $20 \%$ of income earners in developing countries, and also to the percentage of the population in urban areas. It adds that other economic indicators perform very poorly - e.g. private consumption, industrial production, openness of the economy etc.

\subsection{Transport in Island States}

Combining the strands of research into islands and factors influencing car use, it can be seen that research on transport in island states is relatively scarce, and that which does exist tends to be of two types. First, there is some material conducted on the relationships between islands and the rest of the world. For instance, Hoyle (1999) reports on how maritime transport affects the interactions between islands in the Indian Ocean and East Africa, while there is also a body of work connecting SIDS and air transport, economic, environmental and social impacts (e.g. Abeyratne, 1999).

Second, there are several studies conducted on individual islands or groups of islands - e.g. Baguant (1996) and Enoch (2003) investigate transport energy use and policy respectively in Mauritius; Enoch et al (2004) reports on transport policy and emissions in Cuba; while Attard (2005) draws attention to the Maltese transport situation. In addition, there is also a whole raft of articles referring to transport policy in Singapore (e.g. Willoughby, 2001), which is partly due to the early adoption of transport demand management measures there. Finally, it is useful to report some per capita mobility (km/capita) estimates arising from these and other studies, in order to examine the range of values calculated. Overall though, none of the literature appears to have looked at island states as an entity in order to explore a diverse range of variables on apparent levels of car use.

\subsection{Aim, objectives and structure}

The aim of this paper is to look at a selection of economic, social and geo-demographic data to see how these may influence the level of car-borne mobility in the designated islands. Specifically, the paper seeks to:

1. Identify the variables most often considered to 'explain' car use;

2. Determine the most important factors influencing car use in the SIDS dataset;

3. Compare the 'best' mobility indicators found in the SIDS dataset with those in the rest of the world in order to highlight any significant differences.

To do this, the paper is structured as follows. Section 2 outlines the methodology adopted, and then

Section 3 reports the findings. Section 4 offers a discussion of the results and conclusions are set out in Section 5. The complete SIDS dataset is presented in the Appendix (Section 6).

\section{Methodology}

The first step was to derive mobility values from per diem oil use to form the dependent variable for the regression analysis. This fuel use data was then converted into the mobility values by adapting the socalled ASIF model ${ }^{1}$ (see Equation 1).

$Y_{\text {mob }}=F_{\text {consumed }}{ } I_{\text {fuel economy }}{ }^{*}\left(P^{-1}\right)$

Equation 1: The 'ASIF' calculation process for apparent mobility

This dependent variable value is termed 'apparent mobility' in this study (as the fuel data utilised is the 'apparent consumption'). Fuel economy (I) is held constant at 8.56 litres/100 km as consistent with other findings (Heavenrich, 2005; Vasconcellos, 2001; Wright and Fulton, 2005).

The next step was to construct a small islands data set of the 45 SIDS (see Appendix for full set and reduced set). Table 2 links the explanatory variables with the key characteristics of SIDS reported in Table 1 , and references the data sources used.

\footnotetext{
${ }^{1}$ ASIF allocates $\mathrm{A}$ to passenger and freight travel, $\mathrm{S}$ (travel shares by mode and vehicle type), I (fuel efficiency) and $\mathrm{F}$ (fuel use by fuel type and $\mathrm{CO}_{2}$ emissions per unit fuel use) (Schipper and Marie-Lilluiu, 1999). The modified ASIF equation shows that (y) mobility (in km per yr) is approximated by fuel consumed, $F$, (litre per yr) multiplied by the appropriate fuel economy (I), and finally divided by the entire population $(\mathrm{P})$, to yield mobility on a per capita basis. Mobility in this instance represents just one share (S) of the overall activity (A).
} 
Table 2: Data set used for ASIF and multiple regression exercises

\begin{tabular}{|c|c|c|}
\hline Variable name (units) & Variable type & Source \\
\hline $\begin{array}{l}\text { Fuel economy (constant - } \\
8.6 \mathrm{~km} / \text { litre or } 20 \mathrm{mpg})\end{array}$ & ASIF component & $\begin{array}{l}\text { Heavenrich (2005); Padam and Singh } \\
\text { (2005); Wright and Fulton (2005). }\end{array}$ \\
\hline Fuel consumed (litre/year) & ASIF component & $\begin{array}{l}\text { Energy Information Administration (USDOE, } \\
\text { 2003); SPREP (2002) for Palau, Marshall } \\
\text { Islands, Nauru and Kiribati }\end{array}$ \\
\hline Population (persons) & $\begin{array}{l}\text { ASIF component and } \\
\text { Demographic }\end{array}$ & SIDS Pocketbook (UN, 2003a) \\
\hline $\begin{array}{l}\text { Apparent mobility (km /yr- } \\
\text { person)* }\end{array}$ & ASIF (dependent) & Derived from above. \\
\hline Area $\left(\mathrm{km}^{2}\right)$ & Smallness & SIDS Pocketbook (UN, 2003a) \\
\hline Isolation index (index) & Remoteness & Island Directory (UN, 1998) \\
\hline Urban population (\%) & Demographic & SIDS Pocketbook (UN, 2003a) \\
\hline Population density (pers $/ \mathrm{km}^{2}$ ) & Demographic & Derived from above. \\
\hline GDP (\$/capita) & Economic & $\begin{array}{l}\text { SIDS Pocketbook (UN, 2003a) and CIA } \\
\text { World Fact Book (CIA, 2005) }\end{array}$ \\
\hline Roads (km) & Smallness & $\begin{array}{l}\text { IRF World Road Statistics (IRF, 2003) and } \\
\text { some Europa Handbook (2005/6) values }\end{array}$ \\
\hline Vehicles/1000 persons & Economic & IRF World Road Statistics (IRF, 2003) \\
\hline Vehicles/km road & Economic & Derived from above. \\
\hline $\begin{array}{l}\text { Fuel price, diesel and petrol } \\
\text { (US } \phi / l i t r e)\end{array}$ & Economic & $\begin{array}{l}\text { GTZ (Metschies, 2003) and internet values } \\
\text { (Moore et al, 2006). }\end{array}$ \\
\hline
\end{tabular}

*Note: mobility was derived from apparent consumption of both gasoline and fuel oils; the full method is shown in Footnote 1.

A range of linear multiple least squared regression analysis models - forward, simultaneous, stepwise and backward methods - was then applied (ANOVA) to the data set in extracted from Table 1. For a fuller description of the methods used, Brace et al (2000) gives an overview.

\section{Results}

The regression findings are reported in Table 3. From this it can be seen that the stepwise model used was significant (see columns 4-5). The standardised coefficients are listed in column 2 (see $\beta$ ) with significance values in column 3 (p). For the model, the number of island states analysed was 38 , while the final matrix consisted of 410 data items (see Appendix for further details). Collinearity diagnostics detected a tolerance value of $0.22-0.79$ (not presented here). Meanwhile the maximum correlation between coefficients was -0.682 between GDP and vehicles per unit road length and thus the relationships between variables analysed were deemed acceptable (i.e. they were less than 0.8 ).

Table 3: Regression model results for a group of 38 island states.

\begin{tabular}{lllll}
\hline Independent Variables & $\begin{array}{l}\text { Correlation } \\
\text { Coeff. } \\
(\boldsymbol{\beta})\end{array}$ & $\begin{array}{l}\text { Significance } \\
(\mathbf{p}<\mathbf{0 . 0 0 0 )}\end{array}$ & $\begin{array}{l}\text { Model } \\
\text { Summary } \\
(\mathbf{d f}, \mathbf{F})\end{array}$ & $\begin{array}{l}\text { Model } \\
\text { Variance } \\
\left(\mathbf{R}^{\mathbf{2}}, \mathbf{a d j} .\right)\end{array}$ \\
\hline GDP & 0.585 & 0.002 & $\mathrm{~F}_{6,28}=$ & 0.794 \\
Vehicles/ km road & 0.491 & 0.005 & 22.8 & \\
Population density & -0.342 & 0.007 & & \\
Urban population & 0.210 & 0.047 & & \\
Surface area & 0.185 & 0.044 & & \\
Population & -0.187 & 0.052 & & \\
\hline
\end{tabular}

Note: excludes Aruba, Cyprus, Nauru, US Virgin Islands and Netherlands Antilles.

From the results, GDP is the strongest factor, but in some methods population density and vehicles per road length or vehicles/1000 inhabitants were also strong indicators for apparent mobility.

Overall, the regression model shows that GDP remains as the most useful single indicator $(\beta \sim 0.7)$, while vehicles/road length $(\beta \sim 0.4)$ and population density $(\beta \sim-0.4)$ contributed significantly to the model. The first of these was a composite variable which was designed to indicate a very rough proxy of congestion. 
The second variable gives a measure of the impact of space and is notable because the relationship is negative - i.e. mobility is less in more densely populated areas. In the backwards method, population also gives a negative correlation for similar reasons to population density. It is noteworthy that the backwards method, which only adds variables if the model improves in significance, ultimately identifies a full 6 factors of the 11 employed. In all cases the isolation index value (reflecting the degree of geographical separation from neighbouring land forms) was found to be insignificant. Area and the square root of area were also found to be insignificant.

Bearing this in mind, Figure 1 depicts the relationship of mobility as a function of wealth, which clearly increases linearly. Specific SIDS cases are labelled and data from lower income-lower mobility is shown as an expanded inset for clarity. Cases are labelled using the International Standards Organisation convention for three letter country codes (see Appendix for codes).

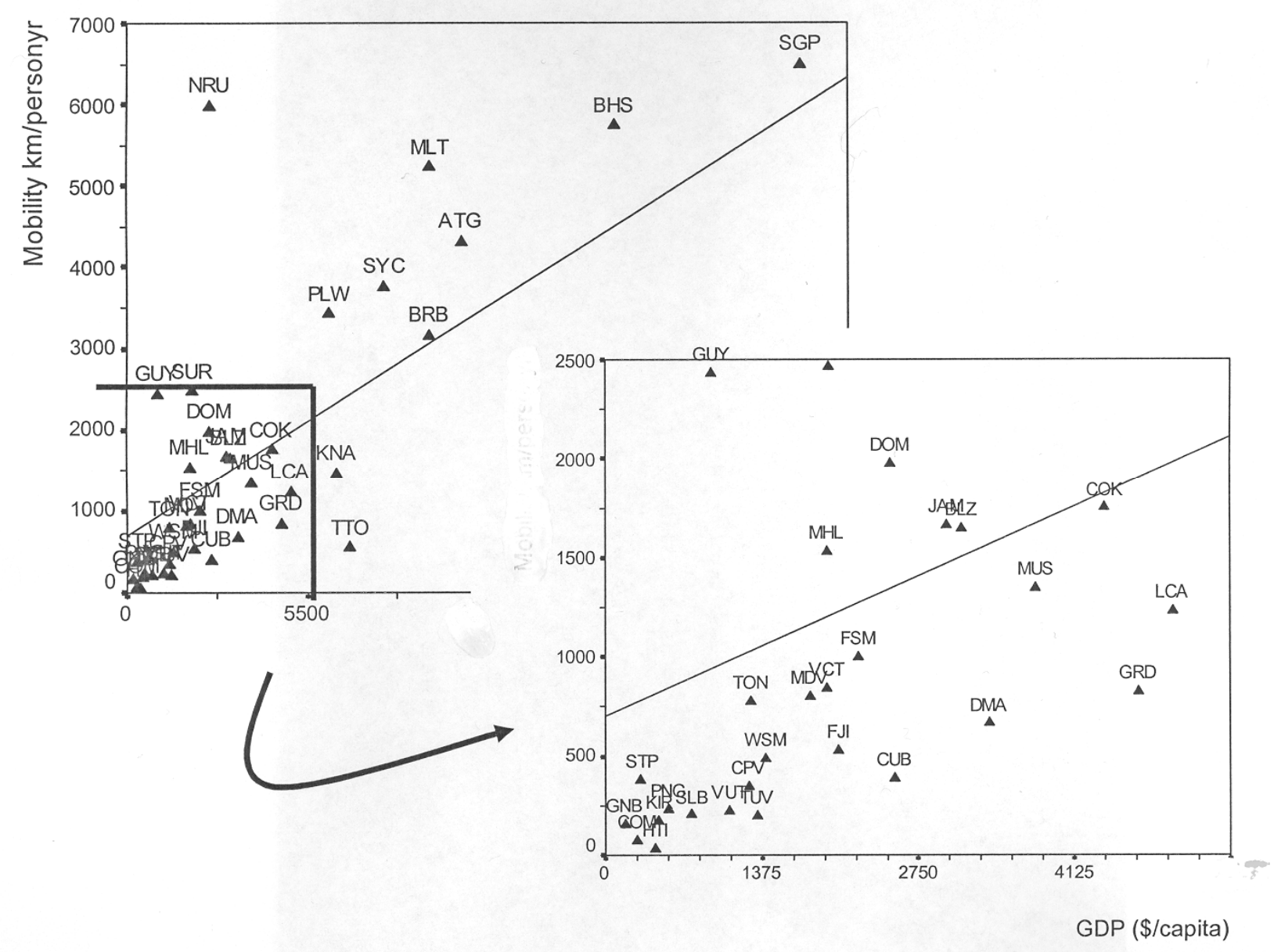

Figure 1: Apparent mobility (km/yr-person) as a function of GDP (\$/person), with a resulting trend line of $y$ (mobility) $=0.323 \times$ GDP +286 , for 38 island states.

Note that the majority of cases lie in the lower and lower-middle income-mobility zone and that high mobility outliers (including US Virgin Islands and NL Antilles), are excluded due to their very high apparent mobility values, which were deemed to be incorrect. This was most likely due to the high use of fuel in these cases for transport not considered here (i.e. agriculturally related, marine, stationary devices, etc). Other (mobility) outliers included Nauru (NRU), Cyprus and Aruba; only NRU is visible on this plot. The plot includes the best fit linear trend line for the 38 island states examined.

The $\mathrm{R}^{2}$ (adjusted) is 0.75 for a best fit line. Relationships dependent on GDP are also observed for the motorisation levels as well as vehicles per road length (see Figure 2) and thus (total) $\mathrm{CO}_{2}$ emissions/person. Many of the SIDS fall below the best fit line especially for those with the lowest incomes.

Single linear trends for mobility, motorisation levels, vehicles/road length as a function of either urbanisation or population density result in very poorly correlated trends and these are not presented here. 


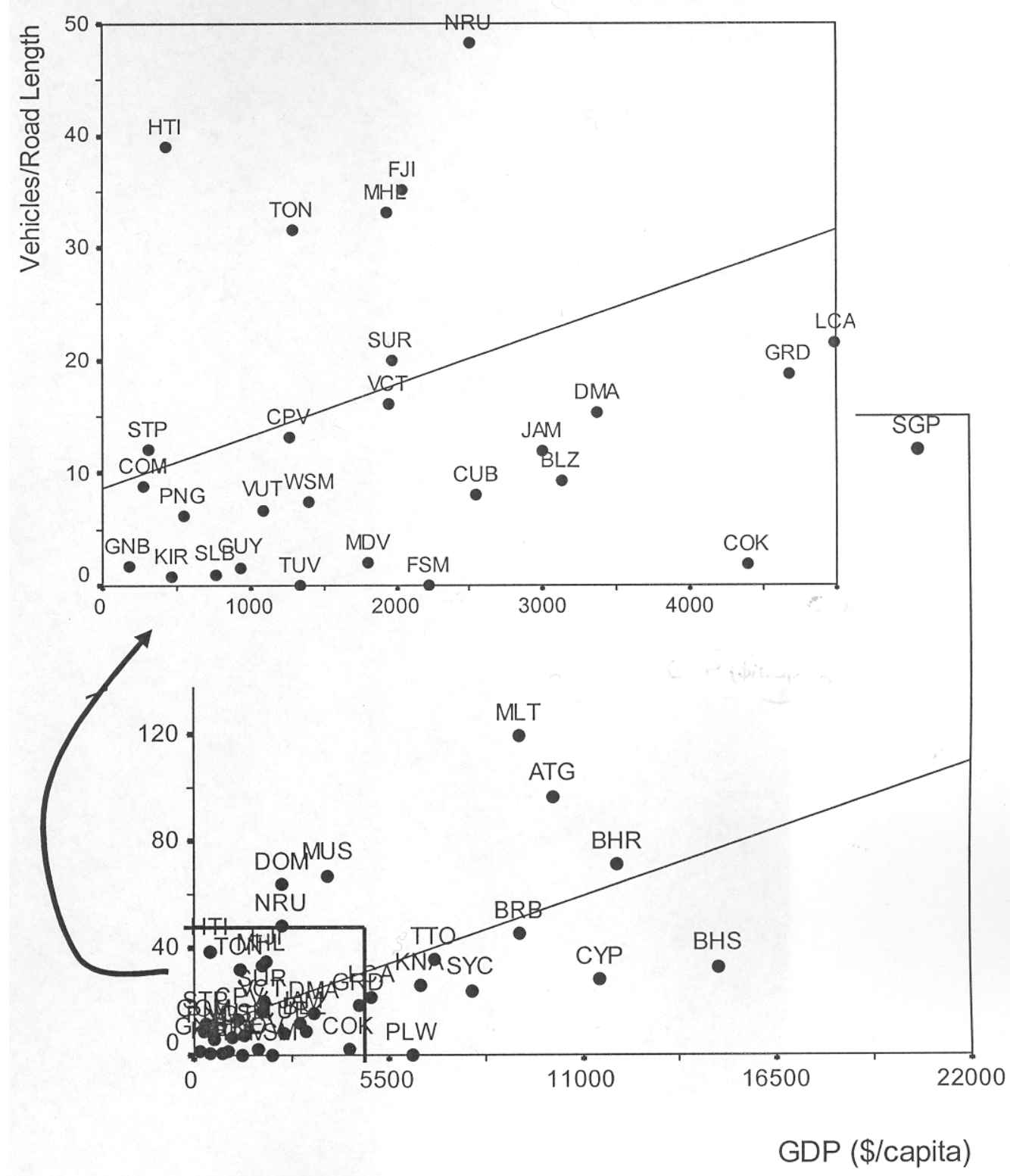

Figure 2: Vehicles per road length (units/km) as a function of GDP (\$/person), for 38 island states yielding a trend line of $y(v e h / \mathrm{km})=4.61 \times 10^{-3} \times \mathrm{GDP}+8.6$.

Figure 2 depicts the composite variable vehicles/road length for each islands case dependent on the GDP of each island $\left(R^{2} \sim 0.4\right)$, while a similar linear relationship is apparent for motorisation as a function of wealth $\left(R^{2} \sim 0.5\right)$. The composite function gives information about vehicle stocks as well as some indication of road network, especially when coupled with island size. As in Figure 1, an inset (above) has been produced here for clarity as many countries lie within the low motorisation $(<50 \mathrm{veh} / \mathrm{km})$ and lower-middle to upper-middle income region.

Lastly, the work examines both overall mobility and overall GDP for SIDS compared with 173 other 'nonSIDS' or rest of the world (ROW) nations (see US DOE (2003) for a full list). Table 4 gives the mean wealth and mobility for each of the conventional UN designated income bands. In this calculation only those countries listed below are analysed, due to the reasons discussed in Section 2. 
Table 4: Aggregate mean values of wealth and mobility for SIDS and world data sets (ROW), by income band, standard error of the mean, shown in brackets for a group of 41 island states.

\begin{tabular}{llllll}
\hline Mean values & Lower Income & Lower Middle & Upper Middle & Highest & All incomes \\
\hline Mean mobility & 179 & 1372 & 2126 & 5322 & $1949(320)$ \\
(SIDS) & $(43)$ & $(340)$ & $(460)$ & $(757)$ & \\
Mean mobility & 544 & 2561 & 6089 & 13,589 & 5557 \\
(ROW) & $(103)$ & $(696)$ & $(1096)$ & $(1736)$ & $(664)$ \\
\hline Mean wealth & 424 & 1934 & 6087 & $16,187(2802)$ & 4876 \\
(GDP, SIDS) & $(73)$ & $(159)$ & $(622)$ & & $(909)$ \\
Mean wealth & 395 & 1640 & 5362 & 23,854 & 7854 \\
(GDP, ROW) & $(30)$ & $(85)$ & $(289)$ & $(1331)$ & $(825)$ \\
\hline Cases (SIDS) & $7^{\mathrm{a}}$ & $17^{\mathrm{b}}$ & $11^{\mathrm{c}}$ & $6^{\mathrm{d}}$ & 41 \\
Cases (ROW) & 47 & 50 & 30 & 46 & 173 \\
\hline
\end{tabular}

Notes: (a) includes GNB, COM, STP, HTI, KIR, PNG, SLB. (b) includes GUY, VUT, CPV, TON, TUV, WSM, MDV, MHL, VCT, SUR, FJI, FSM, DOM, NRU, CUB, JAM, BLZ. (c): DMA, MUS, COK, GRD, LCA, PLW, KNA, TTO, SYC, MLT, BRB. (d): ATG, CYP, BHR, BHS, SGP, ABW. This set excludes Antilles (ANT) and US Virgin Islands (VIR).

Aggregate data analysis shows that while the wealth of SIDS is slightly lower than for the ROW for all cases, the 'apparent mobility gap' is far larger. In other words, both the mean wealth and mobility of citizens on SIDS is less than that for those living in ROW nations. Moreover, when tested using a student's 't-test' these differences are found to be statistically significant at the $95 \%$ confidence interval.

Looking at a more disaggregated level at the GDP values, it can be seen that for three of the four income bands the mean GDP for SIDS appears to be higher. However, because of the large deviation associated with the mean, when statistically tested it is the case that SIDS are poorer in the lower middle and highest quartiles, while in the other two they show equivalence. Meanwhile the mean mobility values by income band are all lower for SIDS than for ROW, although only the upper middle is statistically significantly different.

\section{Discussion}

The study findings show that GDP is the strongest factor, and that vehicles stock indicators (veh/km and veh/1000 population) were also strong, secondary indicators for apparent mobility and this finding has been echoed by others (Gakehiemer, 1999, Button et al, 1993, Schafer and Victor, 2000), albeit for nonisland cases.

Overall the data shows that the small islands have mobility values which are two to three times lower than world values for all income bands, and as an aggregated sub-set, despite the fact that the GDP is roughly the same for the other world countries' bands. The initial set of 41 cases for small islands is indeed less wealthy by a factor of nearly two and less travelled by nearly three times. That set, of 41 , had a stronger correlation for mobility as function of wealth $\left(R^{2} \sim 0.52\right)$ versus that found for the world set $\left(R^{2} \sim 0.4\right)$ but this is probably explained in the very wide variation found in such a large world set (173 cases). This lower apparent mobility can be interpreted partly due to islanders being able to achieve their desired level of mobility with less motorised travel.

More specifically for the SIDS dataset, the adjusted $R^{2}$ of 0.75 relating mobility to GDP alone is slightly higher than that reported by Gakenheimer (1999), which instead found that motorisation was correlated with average annual income of top $20 \%$ of the population. It would thus seem that economic performance (as measured by GDP) is the dominant explanatory factor of motorised mobility, and it is even more strongly correlated in SIDS than for the ROW nations. Other than GDP, the only other economic indicator of note is vehicles per road length or vehicles per 1000 people - the rest are much less significant, but they provide some useful insights.

Looking at the demographic factors, the relationships revealed here show positive correlations with vehicles per road $\mathrm{km}$, or vehicles per 1000 inhabitants, and urban population. This is an indication of both the importance of transport stocks, such as vehicles, but also to access to these vehicles and affordability of fuel and transport costs. A measure of this which was not assessed should include overall costs of transport to users. This could be in real cost terms, or by a proxy such as percentage of GDP due to transport. As stated before the value might be skewed by air transport, thus annual road expenditures per capita may be better for determination of mobility on SIDS. Although not necessarily demographic, an inclusion of public transport, when available, would also be recommended to give a fuller picture of individual mobility. Here, urban population was significant in the modelling and this supports the study's trend which shows that motorisation is positively correlated to urbanisation for twelve low income countries. However, the more strongly negative correlation between population density (which could also be an approximation for urbanisation) and mobility seem to balance this result to some degree. The increased density (or urbanisation level) indicate that within highly populated areas that motorised mobility 
tends to fall. This matches work by Kenworthy and Laube (1999) even though that study focused more on mobility in cities, and used quite different indicators to represent the degree of urbanisation.

Car ownership was also found to be a function of increased urban density for the year 1990 (Kenworthy and Laube, 1999). In general they found that transit passenger mobility, car use per capita and urban density (in that order) correlated with gross regional product for developed cities, but less well for all cities (i.e. developed plus developing).

Also, whereas fuel prices are reported as being a key indicator of car use in Button et al (1993), they do not appear to be significant in the analysed SIDS dataset. There are probably multiple reasons for this but in part this could be due to the cross sectional approach combined with the relatively poor quality of the data.

In attempting to determine whether the particular SIDS-specific characteristics have an impact on 'internal' travel patterns, it could be argued that 'area' is only weakly correlated with mobility (just under half the effect of population density i.e. 0.19 compared with -0.34). A second measure of smallness - road length only becomes significant when combined with the number of vehicles to form a composite variable. Meanwhile, the remoteness (as measured by the isolation index which 'measures' purely distance-based isolation) suggests that in the case of the SIDS, no effect on motorised mobility in this study could be observed. Clearly there are arguments against this theory. For example Abeyratne (1999) points out some of the consequences of those SIDS which have extensive air transport networks and one would expect that SIDS with high air links might have higher apparent mobility levels. This work could not easily though link isolation values with mobility, but further work should consider air connectivity and its impacts.

Overall the data shows that the small islands have mobility values which are $1.9-3$ times lower than world values for all income bands, and as an aggregated sub-set, despite the fact that the GDP is roughly the same for the other world countries' bands. The full set of 41 cases for small islands is indeed less wealthy by a factor of 1.6 times and less travelled by 2.9 times. That set, of 41 , had a stronger correlation in trendline for mobility as function of wealth $\left(R^{2} \sim 0.52\right)$ versus that found for the world set $\left(R^{2} \sim 0.4\right)$ but this is probably explained in the very wide variation found in such a large world set (173 cases).

Regarding limitations to this work there are two areas in particular worthy of comment when considering mobility values. These values are in Table 5.

Table 5: Apparent and reported values of mobility for selected islands

\begin{tabular}{lll}
\hline Island & $\begin{array}{l}\text { Apparent mobility } \\
\text { (km/year) }\end{array}$ & $\begin{array}{l}\text { Reported mobility } \\
\text { (km/year) }\end{array}$ \\
\hline Cuba & 390 & $750(\mathrm{ONE}, 2002)$ \\
Malta & 5228 & $3750(\mathrm{EC}, 2006)$ \\
Cyprus & 8016 & $4384(\mathrm{EC}, 2006)$ \\
Singapore & 6498 & $3570($ Kenworthy and Laube, 1995) \\
Mauritius & 1351 & 1232 (Baguant, 1996) \\
\hline
\end{tabular}

In three cases, (Malta, Cyprus and Singapore) the ASIF calculations were higher than the previous study results, although once the Singapore data is adjusted for its age the difference would probably not be too great. Thus, only the Cyprus calculations are probably significantly different. In the case of Cuba, the ASIF figures are also probably too high given that the official statistics include a very high number of public transport and shared private transport trips thanks to the country's unique transport situation (Enoch et al, 2004). Lastly, once the age of the data is factored in for the Mauritian case, it is likely that the current 'actual' average mobility there is now far higher than the ASIF estimate. Overall, it could be argued that three cases are fairly reasonable estimates while one is far too high and one is far too low. The following paragraphs examine why this may be the case.

In particular, there is an issue of too much fuel being converted into apparent mobility as a certain amount of fuels are held as stocks, while distillate fuel oil covers a broad range of uses such as agricultural machinery. Here it was assumed that road transport used the majority of this fuel - thus perhaps overestimating per capita motorised mobility.

On the other hand, the apparent mobility value does not account for average vehicle occupancies - which are very difficult to obtain for most countries examined here. Therefore, an occupancy of one person per vehicle was assumed, which is obviously much lower than the actual persons/trip made, and so in this way the apparent mobility values calculated will be lower than the actual values. It should also be noted that in the case of many developing states, including some SIDS, other modes to the car - i.e. public transport and powered two wheelers (PTWs) represent a significant modal share of motorised trips and yet are not 
modelled here due to a lack of suitable data. Similarly, human-powered mobility such as walking and cycling, nor air or sea travel are modelled, although it is recognised that these may be significant. Certainly in the case of island nations sea travel may be very significant, especially for nations which are formed of a number of islands. Given these omissions, it is likely that the actual mobility of many of these countries is somewhat higher than those derived from the study.

The second issue concerns the use of such a simplistic model. Here it is argued that the low quality of the data suggests that using more sophisticated techniques would add little to the usefulness of the results, although the use of per capita based variables does reduce potential problems of heteroscedacity which accompany the wide variations in countries' populations, as well as the large spread in GDP (Button et al, 1993). Others address this issue by only implementing the higher band of individuals countries GDP (Gakenheimer, 1999) on the premise that those persons earning more have greater access to travel, and thus are more mobile. In this case, a survey of transport issues in SIDS is currently being undertaken by the authors to explore the contextual circumstances in more detail.

\section{Conclusions}

In conclusion, the factors identified by previous work - both relating to island states and mobility - include population size, degree of urbanisation, area, GDP, road length, vehicle ownership, remoteness and fuel price - which are tested in the model used in the study.

From these, it is reported that by far the most significant factor for influencing car use in the SIDS dataset is GDP, in common with the rest of the world. After that, there are two other primary factors - namely vehicle-related and population-related variables. Thus, vehicles per 1000 population, and vehicles per unit road length, population density (inversely) and urban population are significant in at least one of the regression models. Finally, neither fuel price nor degree of isolation/remoteness seems to have on bearing on apparent mobility in this study.

When comparing the SIDS results with those of the rest of the world, this study shows that mobility is significantly lower for the SIDS by a factor of nearly two times up to three times, when compared to a much larger set of national data for the rest of the world. This was also found to be true for all four income bands. From an economist's perspective, such a finding may imply a loss of welfare by islanders, although more likely is the fact that people's need or desire to travel is less than elsewhere if or when all available destinations are closer. Wealth, as measured by GDP, is observed to be marginally higher than the rest of the world averages for income bands at the lower end of the spectrum, but they are statistically lower for the highest income band and when aggregated.

If these conclusions are applied to policy, more information on the specific contextual conditions evident on each island would really need to be known (hence the current survey alluded to earlier). Indeed, it could be argued that the apparent 'disconnectedness' of islands from other territories and influences has led to some rather extreme outcomes. Thus, Cuba has experienced severe economic pressures for nearly 50 years while the Government of Singapore has capitalised on its own special circumstances to implement a whole raft of innovative yet potentially controversial transport policy measures since the early 1970s.

However, there are some tentative hypotheses that can be drawn to be tested in future work. Thus, returning to the intrinsic vulnerabilities of island states set out in Table 1, the implications would seem to be:

\section{Smallness}

- Islands generally see facilities located close to one another.

- Political structures fairly flat vis a vis larger countries, therefore making decision making chains rather more direct.

One would suspect that while the first factor would negate the need or demand for travel to some extent, the second may well increase pressure on decision makers to enhance rather than restrict mobility.

\section{Remoteness}

- Increased levels of remoteness mean high external transport costs limiting the supply of 'transport' (see later).

- It could also mean that the competitive threat from neighbouring jurisdictions (the so-called 'beggar my neighbour policy') is reduced.

The implication here would be that introducing potentially unpopular policies to restrict traffic growth may be more politically feasible than elsewhere. 


\section{Demographics}

- Island populations tend to be concentrated in a limited number of centres.

- Island populations tend to be strongly influenced by rapid population changes.

Together, these trends are likely to exacerbate pressure on land in key locations and thus multiply the externalities caused by the transport system more quickly and more severely than elsewhere.

\section{Economic}

- Diseconomies of scale so relatively expensive to provide transport services and to import vehicles, spare parts, fuel and materials for infrastructure development.

- Islands are particularly vulnerable to fluctuations in energy prices.

These pressures would seem to lead Island Governments to consider managing mobility through restricting travel demand and or improving alternatives rather earlier than elsewhere.

\section{Appendix}

The following tables (A1 to A4) show the datasets for the various countries with units as described in Table 2. Note that (e) refers to an estimated value while NA signifies that the data was not available. Of the initial 45 SIDS, Niue and Tokelau were not analysed due either to size effects and/or to a lack of data, while the US Virgin Islands, Aruba, Netherlands Antilles and Cyprus were removed following the first round of analysis due to outlier effects. In particular, the total apparent consumption of diesel and petrol was very high for these countries and it was not clear what portion of it was due to land transport. Nauru was also removed on by size and fuel consumption basis. Thus the reduced set of 38 islands was used for all statistical results (for example see Table 3, and Figures 1 and 2). However some of the seven islands (which were previously removed) were analysed with respect to wealth and mobility trends in the later analysis as their inclusion did not alter the trendline findings. This is the set of 41 with Aruba, Cyprus and Nauru included (for examples see Table 4).

It should also be noted that Singapore and Bahrain have land bridges and this affects mobility values;

Belize, Guinea-Bissau, Guyana and Suriname also have direct connections to their neighbouring states. A connected neighbour also applies to Haiti and Dominican Republic. In all cases the mobility values here have not been corrected for land bridges, etc. 
Table A1: Lower income countries (7 cases) and associated data set

\begin{tabular}{|c|c|c|c|c|c|c|c|c|c|c|c|c|c|c|}
\hline Country & Code & $\begin{array}{l}\text { Mobility } \\
\text { (km/yr) }\end{array}$ & Population & $\begin{array}{l}\text { Area } \\
\left(\mathrm{km}^{2}\right)\end{array}$ & $\begin{array}{l}\text { Isolation } \\
\text { Index }\end{array}$ & $\begin{array}{l}\text { Urbanisation } \\
(\%)\end{array}$ & $\begin{array}{l}\text { Population } \\
\text { Density } \\
\left(\text { pers } / \mathrm{km}^{2}\right)\end{array}$ & $\begin{array}{l}\text { GDP } \\
(\$ / \text { per })\end{array}$ & $\begin{array}{l}\text { Roads } \\
(\mathrm{km})\end{array}$ & Veh/1000 & Veh/km & $\begin{array}{l}\mathrm{CO}_{2} / \text { cap } \\
\text { (tonnes/yr) }\end{array}$ & $\begin{array}{l}\text { Diesel } \\
\text { (cent/litre) }\end{array}$ & $\begin{array}{l}\text { Petrol } \\
\text { (cent/litre) }\end{array}$ \\
\hline Comoros & COM & 73 & 749000 & 2235 & 49 & 33 & 316 & 278 & 880 & 10.3 & 8.8 & 0.09 & NA & 181 \\
\hline Guinea-Bissau & GNB & 155 & 1257000 & 36125 & 1 & 4.8 & 33 & 174 & 4400 & 6 & 1.7 & 0.18 & 56 & 66 \\
\hline Haiti & $\mathrm{HTI}$ & 36 & 8400000 & 27750 & $20(e)$ & 36 & 293 & 431 & 4160 & 19.3 & 39.0 & 0.17 & 30 & 54 \\
\hline Kiribati & KIR & 174 & 85000 & 726 & 129 & 39 & 113 & 468 & 670 & 5.8 & 0.7 & 0.26 & 58 & 59 \\
\hline Papua New Guinea & PNG & 232 & 5032000 & 462840 & 37 & 13 & 10 & 545 & 19600 & 24.2 & 6.2 & 0.49 & 64 & 94 \\
\hline $\begin{array}{l}\text { Sao Tome \& } \\
\text { Principe }\end{array}$ & STP & 381 & 143000 & 964 & 39 & 47 & 149 & 312 & 320 & 26.9 & 12.0 & 0.54 & 71 & 90 \\
\hline Solomon Islands & SLB & 203 & 479000 & 28896 & 75 & 20 & 15 & 760 & 1360 & 2.8 & 1.0 & 0.34 & 41 & 41 \\
\hline
\end{tabular}

Note: (e) signifies value is an estimate; NA - data not available

Table A2: Lower middle income countries (17 cases) as described in text.

\begin{tabular}{|c|c|c|c|c|c|c|c|c|c|c|c|c|c|c|}
\hline Country & Code & $\begin{array}{l}\text { Mobility } \\
\text { (km/yr) }\end{array}$ & Population & $\begin{array}{l}\text { Area } \\
\left(\mathrm{km}^{2}\right)\end{array}$ & $\begin{array}{l}\text { Isolation } \\
\text { Index }\end{array}$ & $\begin{array}{l}\text { Urbani } \\
\text { sation } \\
(\%)\end{array}$ & $\begin{array}{l}\text { Population } \\
\text { Density } \\
\left(\text { pers } / \mathrm{km}^{2}\right)\end{array}$ & $\begin{array}{l}\text { GDP } \\
\text { (\$/per) }\end{array}$ & $\begin{array}{l}\text { Roads } \\
(\mathrm{km})\end{array}$ & Veh/1000 & Veh/km & $\begin{array}{l}\mathrm{CO}_{2} / \text { cap } \\
\text { (tonnes/y } \\
\text { r) }\end{array}$ & $\begin{array}{l}\text { Diesel } \\
\text { (cent//i } \\
\text { tre) }\end{array}$ & $\begin{array}{l}\text { Petrol } \\
\text { (cent/lit } \\
\text { re) }\end{array}$ \\
\hline Belize & BLZ & 1649 & 236000 & 22696 & 1 & 54 & 10 & 3123 & 2872 & 112.2 & 9.2 & 1.64 & 80 & 120 \\
\hline Cape Verde & CPV & 349 & 446000 & 1033 & 55 & 62 & 106 & 1259 & 1350 & 39.8 & 13.1 & 0.27 & 81 & 140 \\
\hline Cuba & CUB & 390 & $\begin{array}{l}11273 \\
000\end{array}$ & 110861 & 33 & 75 & 101 & 2545 & $\begin{array}{l}60 \\
858\end{array}$ & 43.1 & 8.0 & 2.23 & 45 & 90 \\
\hline $\begin{array}{l}\text { Dominican } \\
\text { Republic }\end{array}$ & DOM & 1977 & 8693000 & 48511 & $20(\mathrm{e})$ & 65 & 172 & 2500 & $\begin{array}{l}12 \\
600\end{array}$ & 93 & 63.8 & 1.53 & 27 & 49 \\
\hline Fiji & FJI & 533 & 832000 & 18274 & 88 & 49 & 45 & 2046 & 3440 & 145.4 & 35.2 & 0.91 & 73 & 91 \\
\hline Guyana & GUY & 2433 & 765000 & 214969 & 1 & 38 & 4 & 936 & 7970 & 16.8 & 1.6 & 1.34 & 27 & 31 \\
\hline Jamaica & JAM & 1667 & 2621000 & 10990 & 50 & 56 & 234 & 2990 & $\begin{array}{l}18 \\
700\end{array}$ & 84.7 & 11.9 & 4.09 & 44 & 52 \\
\hline Maldives & MDV & 806 & 309000 & 298 & 57 & 27 & 976 & 1806 & $50(e)$ & 5.4 & 33.4 & 0.98 & 47 & 54 \\
\hline $\begin{array}{l}\text { Marshall } \\
\text { Islands }\end{array}$ & $\mathrm{MHL}$ & 1529 & 53000 & 181 & 88 & 72 & 383 & 1938 & 65 & 40.3 & 33.1 & 4.63 & 69 & 72 \\
\hline $\begin{array}{l}\text { Micronesia, } \\
\text { Fed. }\end{array}$ & FSM & 1000 & 129000 & 702 & 108 & 28 & 165 & 2215 & 240 & 63.6 & 34.2 & 1.09 & 79 & 73 \\
\hline Nauru & NRU & 5988 & 13000 & 21 & 97 & 100 & 524 & 2500 & 30 & 111 & 48.3 & 10.69 & 50 & 70 \\
\hline $\begin{array}{l}\text { St Vincent \& } \\
\text { Grenadines }\end{array}$ & VCT & 846 & 115000 & 388 & 37 & 55 & 289 & 1940 & 829 & 116 & 16.0 & 1.40 & 41 & 66 \\
\hline Samoa & WSM & 490 & 159000 & 2831 & 87 & 22 & 56 & 1402 & 790 & 37 & 7.4 & 0.83 & 48 & 49 \\
\hline Suriname & SUR & 2471 & 441000 & 163820 & 1 & 74 & 2.7 & 1965 & 4492 & 204 & 20.0 & 4.78 & 41 & 56 \\
\hline Tonga & TON & 778 & 100000 & 650 & 103 & 38 & 151 & 1284 & 680 & 215 & 31.6 & 1.21 & 59 & 54 \\
\hline Tuvalu & TUV & 200 & 10000 & 26 & 82 & 52 & 423 & 1342 & 8 & 88 & 109.6 & 0.50 & 73 & 74 \\
\hline Vanuatu & VUT & 226 & 207000 & 12189 & 62 & 20 & 16 & 1085 & 1070 & 35 & 6.7 & 0.30 & 84 & 82 \\
\hline
\end{tabular}

Page 11 of 15, Enoch and Warren, Transp. Res. A 42 (2008) 1208-1219. 
Table A3: Upper middle incomes (11 cases) as described in the text.

\begin{tabular}{|c|c|c|c|c|c|c|c|c|c|c|c|c|c|c|}
\hline Country & Code & $\begin{array}{l}\text { Mobility } \\
\text { (km/yr) }\end{array}$ & Population & $\begin{array}{l}\text { Area } \\
\left(\mathrm{km}^{2}\right)\end{array}$ & $\begin{array}{l}\text { Isolation } \\
\text { Index }\end{array}$ & $\begin{array}{l}\text { Urbanisation } \\
(\%)\end{array}$ & $\begin{array}{l}\text { Population } \\
\text { Density } \\
\left(\text { pers } / \mathrm{km}^{2}\right)\end{array}$ & $\begin{array}{l}\text { GDP } \\
\text { (\$/per) }\end{array}$ & $\begin{array}{l}\text { Roads } \\
(\mathrm{km})\end{array}$ & Veh/1000 & Veh/km & $\begin{array}{l}\mathrm{CO}_{2} / \mathrm{cap} \\
\text { (tonnes/yr) }\end{array}$ & Diesel (cent/litre) & $\begin{array}{l}\text { Petrol } \\
\text { (cent/litre) }\end{array}$ \\
\hline Barbados & BRB & 3154 & 269000 & 430 & 46 & 50 & 622 & 9255 & 1600 & 268 & 45.1 & 3.34 & 53 & 66 \\
\hline Cook Islands & COK & 1751 & 20000 & 236 & 106 & 59 & 81 & 4388 & 320 & 30 & 1.9 & 1.10 & 79 & 82 \\
\hline Dominica & DMA & 667 & 70000 & 751 & 4 & 71 & 95 & 3367 & 780 & 171 & 15.4 & 1.16 & 55 & 31 \\
\hline Grenada & GRD & 828 & 94000 & 344 & 34 & 38 & 270 & 4682 & 1040 & 208 & 18.8 & 1.95 & 41 & 54 \\
\hline Malta & $\mathrm{MLT}$ & 5228 & 393000 & 316 & 35 & 91 & 1234 & 9245 & 2222 & 677 & 119.7 & 4.48 & 53 & 87 \\
\hline Mauritius & MUS & 1351 & 1210000 & 2040 & 87 & 43 & 615 & 3779 & 2000 & 111 & 67.2 & 1.41 & 56 & 74 \\
\hline Palau & PLW & 3420 & 20000 & 459 & 80 & 40 & 72 & 6179 & 61 & 276 & 90.5 & 11.70 & 59 & 54 \\
\hline Saint Kitts \& Nevis & KNA & 1454 & 38000 & 269 & 41 & 34 & 169 & 6396 & 320 & 216 & 25.7 & 2.71 & 43 & 69 \\
\hline St Lucia & LCA & 1237 & 151000 & 622 & 41 & 38 & 238 & 4994 & 1210 & 172 & 21.5 & 1.31 & 72 & 79 \\
\hline Seychelles & SYC & 3751 & 83000 & 455 & 77 & 64 & 177 & 7850 & 373 & 108 & 24.1 & 2.39 & NA & 44 \\
\hline Trinidad \& Tobago & TTO & 545 & 1306000 & 1306 & 15 & 74 & 4528 & 6817 & 8320 & 228 & 35.8 & 16.82 & 21 & 40 \\
\hline
\end{tabular}

Table A4: Highest income countries (6 cases) and associated data set.

\begin{tabular}{|c|c|c|c|c|c|c|c|c|c|c|c|c|c|c|}
\hline Country & Code & $\begin{array}{l}\text { Mobility } \\
(\mathrm{km} / \mathrm{yr})\end{array}$ & Population & $\begin{array}{l}\text { Area } \\
\left(\mathrm{km}^{2}\right)\end{array}$ & $\begin{array}{l}\text { Isolatio } \\
\mathrm{n} \\
\text { Index }\end{array}$ & $\begin{array}{l}\text { Urbanisation } \\
(\%)\end{array}$ & $\begin{array}{l}\text { Population } \\
\text { Density } \\
\left(\text { pers } / \mathrm{km}^{2}\right)\end{array}$ & $\begin{array}{l}\text { GDP } \\
(\$ / \text { per })\end{array}$ & $\begin{array}{l}\text { Roads } \\
(\mathrm{km})\end{array}$ & $\begin{array}{l}\text { Veh/100 } \\
0\end{array}$ & Veh/km & $\begin{array}{l}\mathrm{CO}_{2} / \mathrm{cap} \\
\text { (tonnes/yr) }\end{array}$ & $\begin{array}{l}\text { Diesel } \\
\text { (cent//i } \\
\text { tre) }\end{array}$ & $\begin{array}{l}\text { Petrol } \\
\text { (cent/litre) }\end{array}$ \\
\hline $\begin{array}{l}\text { Antigua and } \\
\text { Barbuda }\end{array}$ & ATG & 4311 & 65000 & 442 & 41 & 37 & 152 & 10204 & 250 & 373 & 96.9 & 5.18 & 62 & 62 \\
\hline Aruba & ABW & 4685 & 108000 & 193 & 18 & 21 & 489 & 28000 & 800 & 480 & 64.8 & 17.33 & NA & 84 \\
\hline Bahamas & BHS & 5738 & 312000 & 13878 & 39 & 89 & 22 & 14856 & 2693 & 284 & 32.9 & 5.58 & NA & 66 \\
\hline Bahrain & $\mathrm{BHR}$ & 2684 & 663000 & 694 & 13 & 92 & 944 & 12012 & 3459 & 372 & 71.3 & 22.39 & 19 & 27 \\
\hline Cyprus & CYP & 8016 & 793000 & 9251 & 27 & 57 & 86 & 11504 & 13943 & 494 & 28.1 & 6.88 & 44 & 83 \\
\hline $\begin{array}{l}\text { Netherlands } \\
\text { Antilles }\end{array}$ & ANT & $\begin{array}{l}>20 \\
000\end{array}$ & 219000 & 800 & 22 & 70 & 269 & 12149 & 600 & 414 & 151.1 & 30.92 & NA & 58 \\
\hline Singapore & SGP & 6498 & 4164000 & 685 & 3 & 100 & 6075 & 20544 & 3130 & 171 & 227.5 & 8.56 & 38 & 85 \\
\hline $\begin{array}{l}\text { US Virgin } \\
\text { Islands }\end{array}$ & VIR & $\begin{array}{l}>20 \\
000\end{array}$ & 124000 & 347 & $46(e)$ & 46 & 271 & 17200 & 1257 & 511 & 50.4 & 94.41 & 59 & 60 \\
\hline
\end{tabular}




\section{Acknowledgements}

The authors are indebted to P. Garthwaite (Open University) and D. Pitfield (Loughborough University), for advice on the methodology and to Anare Matakiviti of South Pacific Applied Geoscience Commission (SOPAC) for supplying fuel data for Micronesian countries. Thanks are also expressed to HR Jones, GA Moore and LJE Price for their efforts in the process of putting this paper together and to the referees for their valuable comments.

\section{References}

Abeyratne RIR (1999) Management of the environmental impact of tourism and air transport on small island developing states, Journal of Air Transport Management, 5, 31-37.

Armstrong HW and Read R (2006) Determinants of economic growth and resilience in small states (Chapter 7, pp. 131-155) (in eds. Briguglio L, Cordina G, Kisanga EJ) Building the economic resilience of small states. Island and Small States Institute of the University of Malta and the Commonwealth Secretariat, London, Formatek Publishing, Malta.

Attard M (2005) Land transport policy in a small island State - the case of Malta, Transport Policy, 12, 23-33.

Baguant J (1996) Mauritius, (in ed. Bhagavan MR), Transport Energy in Africa. African Energy Policy Research Network, Zed Books, London.

Baldacchino G (2005) The Bridge Effect http://www.islandstudies.ca/bridgeeffect.html, last accessed February 2008.

Button K, Ngoe N and Hine J (1993) Modelling vehicle ownership and use in low income countries, Journal of Transport Economics and Policy, 27, 51-67.

Brace N, Kemp R, Snelgar R (2000) SPSS - guide to data analysis using SPSS for Windows (see esp. Ch. 7, 205- 220, Multiple regression), Palgrave, New York.

Briguglio L (1995) Small island developing states and their economic vulnerabilities, World Development, 23, 1615-1632.

Central Intelligence Agency (US) (2005) The World Factbook 2005, Central Intelligence Agency, Washington DC. Visit http://www.cia.gov. Last accessed 20 December 2005.

Conway D (1998) Microstates in a macroworld (in eds. Klak T) Globalisation and Neo-liberalism in the Caribbean context, Rowman and Littlefield, Oxford, 51-63.

Enoch MP (2003) Transport practice and policy in Mauritius, Journal of Transport Geography, 11, 297-306.

Enoch MP, Warren JP, Rios HV and Menoyo EH (2004) The effect of economic restrictions on transport practices in Cuba, Transport Policy, 11, 67-76.

Europa (2005/6) Europa Handbook Series: Caribbean (12 ${ }^{\text {th }}$ Edition); Middle East and North Africa ( $34^{\text {th }}$ Edition); Far East and Australasia ( $37^{\text {th }}$ Edition); Africa - South of the Sahara $\left(34^{\text {th }}\right.$ Edition). Europa Publications, London.

European Commission (2006) EU Energy and Transport in Figures, Statistical Pocketbook 2005, European Commission, Brussels.

Gakenheimer R (1999) Urban mobility in the developing world, Transportation Research A, 33, 671-699. 
Heavenrich RM (2005) Light-Duty automotive technology and fuel economy trends: 1975 through 2005, Technical Report EPA 420-S-05-001, Advanced Technology Division, Office of Transportation and Air Quality, US Environmental Protection Agency, Washington DC, July.

Hoyle B (1999) Port concentration, inter-port competition and revitalisation: the case of Mombassa, Kenya, Maritime Policy and Management, 26(2), 161-174.

International Road Federation (2003) World Road Statistics 2002, IRF, Geneva.

Kakazu H (1994) Sustainable development of small island economies, Westview Press, Oxford, UK.

Kenworthy JR and Laube FB (1999) Patterns of automobile dependence in cities, Transportation Research A, 33, 691-723.

Kenworthy JR and Laube FB (2001) Millennium Cities Database for Sustainable Transport, International Association of Public Transport and Institute for Sustainability and Technology Policy, Brussels.

King R (1993) The geographical fascination of islands (in eds. Lockhart D G, Drakakis-Smith $\mathrm{D}$ and Schembri J) The development process in small island states, Chapter 2, 13-37, Routledge, London.

Lockhart DG, Drakakis-Smith D and Schembri J (1993) The development process in Small Island Developing States, Routledge, London.

McCall G (1994) Nissology: a proposal for consideration, Journal of the Pacific Society, 17(23), (63-64), 1-14.

Metschies GP (2003) GTZ (German technical cooperation) International Fuel Prices, $3^{\text {rd }}$ Edition, May. Visit http://www.gtz.de/de/dokumente/en international Fuel Prices 2003.pdf. Last accessed 20 May 2006.

Moore GA, Jones HR and Warren JP (2006), Diesel and gasoline fuel prices in small island developing states: An internet-based survey, Unpublished Report, Open University, Cambridge, UK, May.

ONE (2002) Annuario Estadístico de Cuba 2002, Oficina Nacional de Estadísticas, Havana.

Padam S and Singh SK (2004) Urbanization and urban transport in India: the search for a policy, Trasporti Europei, 27, 26-44.

Pelling M and Uitto JI (2001) Small Island Developing States: Natural disaster vulnerability and global change, Environmental Hazards, 3, 49-62.

Schafer A and Victor DG (2000) The future mobility of the world population, Transportation Research A, 34, 171-205.

Schipper L and Marie-Lilliu C (1999) Carbon-Dioxide emissions from travel and freight in IEA countries: Indicators of the past... and the long-term future? KFB Meddelande, Stockholm.

Simon D (1996) Transport and development in the Third World, Routledge, London.

Slade TN (1999) Editorial, Special issue on Small Island Developing States, Natural Resources Forum, 23(3), 185-186.

South Pacific Regional Environment Program (2002) Fuel Usage in Micronesia, SPREP. Visit http://www.sprep.org. Last accessed 9 September 2006. 
Tanner JC (1983) International comparison of cars and car usage, TRRL Report 1070, Access and Mobility Division, Transport Operations Department, Transport Road Research Laboratory, Crowthorne, Berkshire, UK.

United Nations (1998) Island Directory, alphabetical listing of islands of the world, United Nations, New York. Visit http://islands.unep.ch/lindex.htm. Last accessed 15 May 2006.

United Nations (2003a) World Statistics Pocketbook: Small Island Developing States, Statistics Division, Department of Economics and Social Affairs, Series V, Number 24/SIDS, United Nations, New York, March. Visit http://www.unstats.un.org/unsd. Last accessed 30 September 2005.

United Nations (2003b) About SIDS. United Nations, New York. Visit http://www.un.org/esa/sustdev/sids/sids.htm. Last accessed 20 July 2005.

US Department of Energy (2003) International Energy Annual 2003, US Department of Energy, Washington DC. Visit: http://www.energy.gov. Last accessed 9 June 2006.

Vasconcellos EA (2001) Urban transport environment and equity: The case for developing countries, Earthscan, London.

Weisser D (2004) On the economics of electricity consumption in small island developing states: A role for renewable energy technologies? Energy Policy, 32, 127-140.

Willoughby C (2001) Singapore's motorisation policies 1960-2000, Transport Policy, 8, 125139.

Wright $L$ and Fulton $L$ (2005) Climate change mitigation and transport in developing nations, Transport Reviews, 25, 691-717.

\author{
File data \\ 7752 \\ ORO submission no 10781 \\ Deposition date 3 Dec 2008 \\ Transportation Research Part A, Policy and practice 42 (2008) 1208-1219.
}

doi:10.1016/.tra.2008.03.008 